\title{
Comparison of Interdisciplinary History and Science Concepts from the Cognitive Aspect with Word Association Test
}

\author{
Sefa Yıldırım, ${ }^{1, *} \&$ Mehmet Akif Haşıloğlu² \\ ${ }^{1}$ Faculty of Science and Letters, Department of History, Ağrı İbrahim Çeçen University, Turkey \\ ${ }^{2}$ Faculty of Education, Education of Math and Science, Department of Science Education. Ağrı İbrahim Çeçen \\ University, Turkey \\ *Correspondence: Faculty of Science and Letters, Department of History, Ağrı İbrahim Çeçen University, Turkey. \\ Tel: 90-0472-215-9994. E-mail: syildirim@agri.edu.tr
}

Received: August 8, 2018

Accepted: August 27, $2018 \quad$ Online Published: September 27, 2018

doi:10.5430/wje.v8n5p41

URL: https://doi.org/10.5430/wje.v8n5p41

\begin{abstract}
This study aims to compare and contrast the connotations of the concepts of "science" and "history" that were formed in the minds of students attending both Faculty of Science and Letters, History Department and Faculty of Education, Science Education Department at Ağrı İbrahim Çeçen University. The participants of the study are 173 students from the History Department, including the whole education level of the department and 71 students from Science Education Department including all classes. The participants were asked what they mean by the concepts of "science" and "history" and what connotations they made. Survey method is used in a descriptive research model. The Word Association Test (WAT) related to history and science has been utilized as a data collection tool. According to findings received after the analysis, it is found that there was no significant difference between cognitive sentence structures of the students, who are attending different disciplines, towards both the concept of history and science. As a result of the Word Association Test, although there are some differences according to the departments of education, many concepts in general are similar. When examining the cognitive sentence structures for the concepts, there is a need for research on the interrelationship of basic concepts with special areas. Thus, this research gains more importance.
\end{abstract}

Keywords: comparison of interdisciplinary education, concept of history, concept of science, cognitive structures, word association test

\section{Introduction}

The university education starts with the introduction of undergraduate education and continues until graduation from an undergraduate program with or without thesis. In general, in the process of university education, students are expected to acquire new perspectives on their profession as well as to acquire knowledge and develop their skills in parallel. However, in recent years, especially in the developed countries, the students are expected to reveal the relations between their profession and other disciplines besides their vocational education, be knowledgeable and use this knowledge for specific purposes.

A student with this feature will not feel confined to a particular discipline; on the contrary, will perceive disciplinary information as a tool for solving the problems that they face or to reach his/her goals. Thinking in this perspective will be an important step in the way of raising individuals who are constantly renewing themselves, using the knowledge they learn and making decisions (Yıldırım, 1996).

For example, although it is in different disciplines, history is not only about history, but about the future as well. In addition to his direct relationships with Sociology, Anthropology, Archeology, Zoology, Literature, Theology, Philosophy, Economics, Finance and Psychology, it is in close relationship with Mathematics and other sciences as well as Architecture and Engineering. These relationships are called "Interdisciplinary Science" and the relationship that History Science has established with these disciplines is called "History of Interdisciplinary Science" (Çoruh, 2010). Interdisciplinary teaching is the effective integration of knowledge about the problem from different fields by organizing the concepts or problems around the teaching. Such an approach is closely related to the way we use 
knowledge and skill in real life. The success of education depends on the ability of knowledge and skills to be used to solve problems or produce ideas (Çoruh, 2010; Yıldırım, 1996).

This necessity requires that we should also know the definitions of the concepts. It is also known that teaching the correct development of concepts are among the aims of education and teaching. In addition, understanding of concepts, knowing the development processes of concepts is also closely related to take them into consideration. As known, concepts are developed in the human mind through the use of different processes. Concepts constitute the building blocks of knowledge, and conceptual relationships also constitute scientific principles. Beginning with their childhood, people learn concepts, abstract units of thought, and words that are their names, classify concepts and find relationships between them. Thus, their knowledge becomes meaningful, they rearrange their knowledge, even produce new concepts and information (YÖK / World Bank, 1997)

It is very important for the purposes of teaching to develop the correct concepts in students' academic careers. Whether or not a student understands or comprehends a concept or idea related to science is also closely related to the meanings s/he attributes as much as how a student organizes the knowledge (Kluegel, 1999; Linder, 1993; Riche, 2000).

Conceptual development, a process that should be given importance from the first years of primary education, is taught completely and correctly in primary education and plays a very important role in understanding the concepts of students throughout their secondary and later academic lives (Bacanak, A., Kü̧̈ük, M. \& Çepni, S.,2004). The concept is automatically selected and used by mind, depending on the nature of the concept and the learning sequence (Ayas, 2005).

Misconceptions that students have can be revealed with the Word Assosiation Test, it can be determined whether students can establish relations between concepts or not, conceptual changes can be revealed in students. When the related literature is examined, it is seen that the word association test is used in many different disciplines (Bahar, Alex, Johnstone \& Sutcliffe, 1999; Bahar \& Kılıç, 2001; Deveci, Köse \& Bayır, 2014; Ekici, Gökmen \& Kurt, 2014; Ercan, Taşdere \& Ercan,2010; Işıkl1, Taşdere \& Göz, 2011; Nakiboğlu, 2008; Yüce \& Önel, 2015; Yücel \& Özkan, 2014). As known, history and science is emphasized on every level of education from the primary school to the end of the university. These concepts are among the most common ideas created by students. It is very important for students to correctly understand the concepts of social sciences and science and to discuss these issues. It will be possible only when the teachers and prospective teachers have sufficient knowledge in the field of social sciences and science that will help to gain this awareness. This can only be possible through conceptual development of students.

When studies on the subject are examined, it is seen that educational researches in recent years have concentrated on revealing the conceptual meanings of students at different disciplinary level in various subjects (Güder, \& Gürbüz 2017; Guven \& Hamalosmanoglu,2012; Karademir, 2017; Özcan, 2006).

At this juncture, however, interdisciplinary teaching and learning needs to be organized around concepts or problems, effectively bringing together information about the problem from different areas. In this context, it is necessary to investigate the relationship between basic professional concepts, interdisciplinary relations and cognitive structures with the word association test in the departments of university students. There is a need for investigation on the mutual relationship of the basic concepts of the professions of each other. Thus it is important to examine cognitive sentence structures of the history department students and the prospective science teachers for both history and science concepts, this has made this research important.

The aim of this study is to examine and compare the cognitive sentences structures of history and science students with the history and science concepts of the students with each other. For this purpose, both history and science students were asked about history and science concepts.

Briefly, this study tries to find out answer or answers to the following question: Are there any differences between the students from department of history and department of science education about the concept of history and science and their conceptual changes? If yes, what sort of differences are they?

\section{Methodology}

Conducted in spring semester, 2017-2018 education year, survey method in a descriptive model was used this study. Survey methods are research approaches aimed at describing the past or present as it exists (Çepni, 2014; Karasar, 1999). 


\subsection{Sampling}

The research was carried out at Agri Ibrahim Çeçen University of in the spring semester of 2017-2018 academic year. Totally 173 students in $1^{\text {st }}, 2^{\text {nd }}, 3^{\text {rd }}$ and $4^{\text {th }}$ grade students in History Department in Science and Letters Faculty and 71 prospective teachers in $1^{\text {st }}, 2^{\text {nd }}, 3^{\text {rd }}$ and $4^{\text {th }}$ grade in Science Education Department in Education Faculty were the participants.

\subsection{Word Association Test (WAT)}

The purpose of this study is to try to find out which key (stimulus) words about "history" bring about in your mind. First, quietly tell yourself the key concept below and write the first word that comes to mind quickly in the gap across the keychain. Fill in the other gaps in the same way with your keyword in mind. For every key concept, you only have 30 seconds. Therefore, try to write your answers as fast as possible.

Write a sentence with at least three lines about the keyword in sentence blank.

\begin{tabular}{|l|l|}
\hline Concept & Word that comes to mind first \\
\hline History & \\
\hline History & \\
\hline History & \\
\hline History & \\
\hline History & \\
\hline History & \\
\hline History & \\
\hline History & \\
\hline History & \\
\hline History & \\
\hline
\end{tabular}

\begin{tabular}{|l|l|}
\hline Concept & Word that comes to mind first \\
\hline Science & \\
\hline Science & \\
\hline Science & \\
\hline Science & \\
\hline Science & \\
\hline Science & \\
\hline Science & \\
\hline Science & \\
\hline Science & \\
\hline Science & \\
\hline
\end{tabular}

Sentence:

Sentence: ....

For the word association test, the students are given the explanatory notes as mentioned above. Students are encouraged to read these directives and are asked to write answers that they think are relevant to the key concept throughout the instruction (Kurt \&Ekici 2013; Özatlı; 2006; Yalvaç; 2008).

Studies related to the WAT have gained momentum in social areas (Bahar \& Kılıç, 2001) as well as in science fields (Cardellini \& Bahar, 2000; Nakipoğlu, Benlikaya \& Bahar, 2002). Studies on WAT can be used not only in the field of science but also in different fields (social sciences, mathematics). In this respect, it is a technique with the flexibility that can be used in different educational environments. Its effectiveness can be examined by comparing it with other techniques in determining the level of conceptual comprehension of students. In addition, the influence of different teaching techniques on the level of conceptual knowledge of students can be measured through WAT.

At the end of the answers, which are corresponded to each key concept, there is the 'related sentence' part. In this part, students are asked to write the sentences that come to their minds about the key concept (Bahar \& Özatl1, 2003, Ercan, Taşdere \& Ercan,2010, Nartgün, 2006).

After applying the word association test, in order to evaluate the results of "History" and "Science" concepts, the concepts of student in their answers were determined one by one. A frequency table about how many kinds of answer concepts are given was prepared.

\subsection{Data Analysis}

In data analysis process, conceptual categories and words that form the categories were determined by two specialists, 
one from History Department and one from Science Education Department and two researches who coded data separately. The obtained data from the Word Association Test, number of words, number of answers and semantic relation techniques were used (Atasoy, 2004). When both researchers make same coding, it is accepted as agreement; however, if they make different coding, it is accepted as disagreement. When one of the researchers contradict with coding, the coding was done by taking the opinion of the other investigator (Miles \& Huberman, 1994). Using the concept cut point technique it was found $60-40 \%, 40-20 \%$ and $20-05 \%$, respectively that indicate the cognitive structure of the students. The aim is to do this, the number of samples of history and science students is different and it was thought that it would be easier to compare the students from two different disciplines conceptually. In the second part of the word association test, the prospective teachers' opinions about the key concept were examined from a scientific perspective to a specialist and the categories were determined.

\section{Results}

Table 1. Examination of History Students' Cognitive Sentence Structures Toward the Concept of "History" and "Science" by means of Word Association Test

\begin{tabular}{|c|c|c|c|c|c|c|c|c|}
\hline Key Concepts & $\mathrm{f}$ & $\begin{array}{l}\text { Sentence including } \\
\text { scientific knowledge } \\
(\%)\end{array}$ & $\mathrm{f}$ & $\begin{array}{l}\text { Non-Scientific or } \\
\text { superficial sentences } \\
(\%)\end{array}$ & $\mathrm{f}$ & $\begin{array}{l}\text { Misconception } \\
\text { sentences (\%) }\end{array}$ & f & $\begin{array}{l}\text { No } \\
\text { Response } \\
(\%)\end{array}$ \\
\hline History & 52 & 30.0578 & 111 & 64.1618 & - & --------- & 10 & 5.7803 \\
\hline Science & 50 & 28.90017 & 114 & 65.8975 & - & --------- & 9 & 5.2023 \\
\hline
\end{tabular}

When the cognitive sentence structures for the "history" and "science" concepts of the students in History Department are examined through the word association test, it was determined that 30.05 of the totally 175 history students about the concept "history" wrote a sentence including scientific knowledge, 64.16 wrote non-scientific or superficial sentence, and 5.78 gave no response. Moreover, when the cognitive knowledge levels of the students in the History Department on the concept of "science" are examined, it was determined that $28.90 \%$ of the sentences include scientific information, $65.89 \%$ was non-scientific or superficial sentence and 5,20\% of the participants did not respond.

Table 2. Examination of Science Education Students' Cognitive Sentence Structures Toward the Concept of "History" and "Science" by Means of Word Association Test

\begin{tabular}{lllllllll}
\hline $\begin{array}{l}\text { Key } \\
\text { Concepts }\end{array}$ & f & $\begin{array}{l}\text { Sentence including } \\
\text { scientific } \\
\text { knowledge (\%) }\end{array}$ & $\begin{array}{l}\text { f } \\
\text { or superficial } \\
\text { sentences (\%) }\end{array}$ & $\begin{array}{l}\text { Non-Scientific } \\
\text { or }\end{array}$ & $\begin{array}{l}\text { Misconception } \\
\text { sentences (\%) }\end{array}$ & $\begin{array}{l}\text { fo Response } \\
\text { (\%) }\end{array}$ \\
\hline History & 10 & 14,0845 & 52 & 73,2394 & 1 & 1,4084 & 8 & 11,2676 \\
Science & 16 & 22,5352 & 52 & 73,2394 & - & --------- & 3 & 4,225 \\
\hline
\end{tabular}

When the cognitive sentence structures for the "history" and "science" concepts of the students in Science Education Department are examined through the word association test, and when the sentence written about the concept "history" was analyzed, it was determined that 14.08 of the totally 71 history students about the concept "history" wrote a sentence including scientific knowledge, 73.23 wrote non-scientific or superficial sentence, $1.40 \%$ wrote misconception sentences, and 11,26 gave no response. In addition, when the cognitive knowledge levels of the students in the Science Education Department on the concept of "science" are examined, it was determined that $22.53 \%$ of the sentences include scientific information, $73.23 \%$ was non-scientific or superficial sentence and $4.22 \%$ of the participants did not respond. 
Table 3. Some Examples of History and Science Concepts through the Word Association Test

\begin{tabular}{|c|c|c|c|}
\hline Key Concepts & $\begin{array}{l}\text { Sentence including } \quad \text { scientific } \\
\text { knowledge }\end{array}$ & $\begin{array}{ll}\text { Non-Scientific } & \text { or } \\
\text { superficial sentences } & \end{array}$ & $\begin{array}{l}\text { Misconception } \\
\text { sentences }\end{array}$ \\
\hline $\begin{array}{l}\text { History Concept } \\
\text { (History Dept.) }\end{array}$ & $\begin{array}{l}\text { It is a scientific branch that } \\
\text { investigate the past events within } \\
\text { the cause and effect relationship. }\end{array}$ & History is a repetition. & \\
\hline $\begin{array}{l}\text { History Concept } \\
\text { (Science Education Dept.) }\end{array}$ & $\begin{array}{l}\text { It is a knowledge that tells about the } \\
\text { past, innovations and shows the } \\
\text { cause and effects, document's and } \\
\text { findings. }\end{array}$ & $\begin{array}{l}\text { It is both the starting and } \\
\text { ending point. Some } \\
\text { interventions done by } \\
\text { science and ideas that } \\
\text { guide the world. }\end{array}$ & $\begin{array}{l}\text { It is a } \\
\text { knowledgeable, } \\
\text { bright and } \\
\text { intellectual path } \\
\text { that was born by } \\
\text { innovations }\end{array}$ \\
\hline $\begin{array}{l}\text { Science Concept } \\
\text { (History Dept.) }\end{array}$ & $\begin{array}{l}\text { Science is to inquire about } \\
\text { environment, nature, universe }\end{array}$ & $\begin{array}{l}\text { Making inventions with } \\
\text { experiments. }\end{array}$ & \\
\hline $\begin{array}{l}\text { Science Concept } \\
\text { (Science Education Dept.) }\end{array}$ & $\begin{array}{l}\text { To conduct research on living and } \\
\text { non-living assets by means of } \\
\text { experimental observational } \\
\text { methods, to investigate knowledge } \\
\text { in a true way in accordance with } \\
\text { methods and principles. }\end{array}$ & $\begin{array}{l}\text { Understanding Nature is in } \\
\text { need of science. }\end{array}$ & \\
\hline Total Sentences & 128 & 329 & 1 \\
\hline
\end{tabular}

When the table containing sample clues about students' key concepts and related words is examined, it is seen that the students have constructed the sentences containing 128 scientific information on the concepts of "history" and "science" besides their 329 non-Scientific or superficial sentences. In the case of misconceptions, only a participant among science education students reflected his/her misconception with this sentence: "It is a knowledgeable, bright and intellectual path that was born by innovations."

Table 4. The Table of $60-40 \%$ Concept Showing the Cognitive Structure of History and Science Education Students Towards the Concept of History and Science

\begin{tabular}{lll}
\hline$\%$ 60-40 & $\begin{array}{l}\text { History Dept. } \\
\text { (Faculty of Science and Letters) }\end{array}$ & $\begin{array}{l}\text { Science Education Dept. } \\
\text { (Faculty of Education) }\end{array}$ \\
\hline Science Concept & Experiment, Science, Physics, & $\begin{array}{l}\text { Experiment, Science, Physics, Chemistry, } \\
\text { Biology }\end{array}$ \\
& Chemistry, Biology & War, History, Ottoman, Atatürk \\
\hline
\end{tabular}

When looking at the percentage table above that shows the cognitive structure of history and science education students, the mostly repeated science concepts in $60-40 \%$ are Experiment, Science, Physics, Chemistry and Biology. In one hand the history students described the history concept as War, Past, Time on the other hand science education students described the history concept as Ottoman, War, Past and Atatürk.

Table 5. The Table of 40-20\% Concept Showing the Cognitive Structure of History and Science Education Students Towards the Concept of History and Science

\begin{tabular}{lll}
\hline$\%$ 40-20 & $\begin{array}{l}\text { History Dept. } \\
\text { (Faculty of Science and Letters) }\end{array}$ & $\begin{array}{l}\text { Science Education Dept. } \\
\text { (Faculty of Education) }\end{array}$ \\
\hline Science Concept & Research, Observation & $\begin{array}{l}\text { Technology, Laboratory, Living } \\
\text { Treaty, Civilization }\end{array}$ \\
History Concept & Treaty, Ottoman, Future & \\
\hline
\end{tabular}


When looking at the percentage table above that shows the cognitive structure of history and science education students, the science concept that they repeat in 40-20\% portion are Research, Observation for the history students. However, science education students described it as Technology, Laboratory, Living. In one hand the history students described the history concept as Treaty, Ottoman, Future on the other hand science education students described the history concept as Treaty, Civilization.

Table 6. The Table of 20-05\% Concept Showing the Cognitive Structure of History and Science Education Students Towards the Concept of History and Science

\begin{tabular}{|c|c|c|c|c|}
\hline & \multicolumn{2}{|c|}{$\begin{array}{l}\text { History Dept. } \\
\text { (Faculty of Science and Letters) }\end{array}$} & \multicolumn{2}{|c|}{$\begin{array}{l}\text { Science Education Dept. } \\
\text { (Faculty of Education) }\end{array}$} \\
\hline \multirow{16}{*}{ 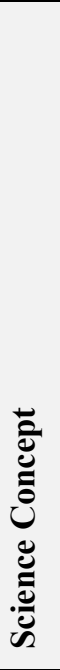 } & Anatomy & Cell & Analysis & Invention \\
\hline & Astronomy & Technology & Research & Human \\
\hline & Atom & Skeleton & Astronomy & Blood \\
\hline & Information & Chromosome & Information & vacuoles \\
\hline & vegetation & Force & Vegetation & Force \\
\hline & Structure of Living & Mass & Invention & Matter \\
\hline & Living creature/s & $\mathrm{Lab}$ & DNA & mitochondria \\
\hline & DNA & Matter & Nature & Mitosis \\
\hline & Nature & Math & Electricity & Newton \\
\hline & Doctor & Microorganism & Photosynthesis & Apron \\
\hline & Element & Mitosis & Observation & positive sciences \\
\hline & Evolution & Molecule & $\mathrm{H} 2$ & RNA \\
\hline & Formula & Newton & Patient & Health \\
\hline & Photosynthesis & Health & Life & Digestive system \\
\hline & Development & Medicine & Animal & Gravity \\
\hline & Animal & Gravity & Cell & \\
\hline \multirow{15}{*}{ 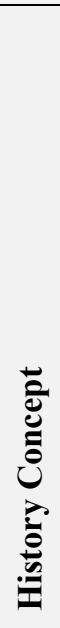 } & Research & Ruins & Research & Hittites \\
\hline & Archaeology & Sword & Archaeology & Castle \\
\hline & Peace & Book & Soldier & ruins \\
\hline & Document & Chronology & Horse & Sword \\
\hline & Information & Culture & Independence & Chronology \\
\hline & Byzantium & Civilization & Peace & Civilization \\
\hline & Jihad & Place & Document & Place \\
\hline & Geography & Mesopotamia & Information & Nations \\
\hline & Age & Nation & Science & Death \\
\hline & Taking Lessons & Objective & Byzantium & Sultan \\
\hline & States & Event & Age & Seljuks \\
\hline & Religion & Sultan & Canakkale & Homeland \\
\hline & The future & Seljuks & Firman & Innovation \\
\hline & Empire & Historical artifacts & Conquests & (Revolution) \\
\hline & Human & & The future & Time \\
\hline
\end{tabular}

When the \% 20-05 Table showing the cognitive structure of the students towards the history and science concept of the students is examined, it is seen that both the history students and the science education students say similar concepts about key concepts of History and Science.

\section{Discussion}

In this study, it was aimed to examine and compare the cognitive sentence structures of the history and science concepts of the students of History Department (Faculty of Science and Letters) and Science Education Department (Faculty of Education). For this purpose, both history and science education students were asked about history and science concepts.

When the cognitive sentence structures for the "history" and "science" concepts of the History Department and Science Education students are examined by means of the word association test, it is found that there is not a significant difference between the percentage of sentences containing scientific information and the percentage of 
sentences containing non-scientific or superficial information. In other words, there was no difference between the "history" concept and the cognitive sentence structures for the "science" concept of the students of Science and History department who were attending different disciplines at universities. When the reasons were examined, this might be resulted that these learners had a joint training program for 8 years starting from primary school. In addition, the fact that the concepts of "history" and "science" is a general concept, there can be another important point that students mentioned the same concepts even though they were in different disciplines.

The concept of the cut point technique which indicates the cognitive structure of the history department and science education students towards the "history" and "science" key concept was determined as $60-40 \%, 40-20-20 \%$ and $20-05 \%$. As a result of the word association test, although there were some differences according to the departments, the results were generally similar among many concepts.

\section{Conclusion}

In this study, when the tables are examined, we observe that the concepts they use are largely similar, although students continue their academic life in different disciplines. When the reasons are examined, it can be deduced that the students took the same courses in a joint training program for 8 years starting from primary school or even nursery school. This indicates that the students have knowledge in different disciplines, and they are individuals that can relate different knowledge with their own profession.

\section{References}

Atasoy, B. (2004). Fen Ö̈̆renimi ve Öğretimi. Asil Yayıncıllk, Ankara.

Ayas, A.(2005). Kuramdan Uygulamaya Fen ve Teknoloji Öğretimi. Ed: Çepni, S. Pegem Akademi Yayıncılık.

Bacanak, A., Küçük, M., \& Çepni, S. (2004). İlköğretim Öğrencilerinin Fotosentez ve Solunum Konularındaki Kavram Yanılgılarının Belirlenmesi: Trabzon Örneklemi. Ondokuzmayls Üniversitesi Eğitim Fakültesi Dergisi, 17, 67-80.

Bahar, M., \& Kılıç, F. (2001). Kelime İletişim Testi Yöntemi İle Atatürk İlkeleri Arasındaki Kavramsal Bağların Araştırılması. IX. Eğitim Bilimleri Kongresi, Abant İzzet Baysal Üniversitesi, Bolu

Bahar, M., \& Özatlı, S. (2003). Kelime İletişim Testi Yöntemi ile Lise 1. Sınıf Öğrencilerinin Canlıların Temel Bileşenleri Konusundaki Bilişsel Yapılarının Araştırılması, Balıkesir Üniversitesi Fen Bilimleri Enstitüsü Dergisi, 5, 75-85

Bahar, M., Alex H., Johnstone \& Sutcliffe, R.G. (1999). Investigation of Students' Cognitive Structure in Elementary Genetics Through Word Association Tests. Journal of Biological Education, 33(3), 134-141. https://doi.org/10.1080/00219266.1999.9655653

Cardellini, L., \& Bahar, M.(2000). Monitoring the learning of chemistry through word association tests. Australian Chemistry Resource Book, 19, 59-69.

Çepni, S. (2014). Araştırma ve Proje Çalı̧̧malarına Giriş, 7.Bask1, Eylül, Trabzon.

Çoruh, H. (2010). Disiplinlerarası Bilim Tarihi Dersi ve Gerekçesi. Tarih Okulu, VII, 7-23

Deveci, H., Çengelci Köse, T., \& Gürdoğan Bayır, Ö. (2014). Öğretmen Adaylarının Sosyal Bilimler ve Sosyal Bilgiler Kavramlarına İliş̧in Bilişsel Yapıları: Kelime İlişkilendirme Testi Uygulaması, Adiyaman Üniversitesi, Sosyal Bilimler Enstitüsü Dergisi, 7(16), 101-124. https://doi.org/10.14520/adyusbd.732

Ekici, G., Gökmen, A., \& Kurt, H. (2014). Öğretmen Adaylarının "Bilgisayar" Kavramı Konusundaki Bilişsel Yapılarının Belirlenmesi. Gazi Üniversitesi Gazi Eğitim Fakültesi Dergisi, 34(3), 357-401.

Ercan, F., Taşdere, A., \& Ercan, N. (2010). Kelime İlişkilendirme Testi Aracılığıyla Bilişsel Yapının ve Kavramsal Değişimin Gözlenmesi, Türk Fen Eğitimi Dergisi, 7(2), 136-154.

Guven, E., \& Hamalosmanoglu, M. (2012). İlköğretim 4. Sınıf Fen ve Teknoloji Ders Kitabındaki Çevre İçerikli Etkinliklerin Disiplinler Arası Yaklaşım Yönünden İncelenmesi. Journal of European Education, 2(1).

Güder, Y., \& Gürbüz, R. (2017). Disiplinler Arası Modelleme Problemi Yoluyla Kavram Öğretimi: Enerji Tasarrufu Problemi. Illkögretim Online, 16(3).

Işıklı, M., Taşdere, A., \& Göz, N.L. (2011). Kelime İlişkilendirme Testi Aracılığıyla Öğretmen Adaylarının Atatürk İlkelerine Yönelik Bilişsel Yapılarının İncelenmesi, Uşak Üniversitesi Sosyal Bilimler Dergisi, 4(1), 50-72. 
Karademir, E. (2017). Fen Öğretiminde Beceri Kavramı ve Disiplinlerarası Kullanımı. Pegem Atıf Indeksi, 1-40. https://doi.org/10.14527/9786052410790

Karasar, N. (1999). Bilimsel araştırma yöntemi. Ankara: Nobel.

Kluegel, J. R. (1999). Sociology 280 Lecture Notes.

Kurt, H., \& Ekici, G. (2013). Determining Biology Student Teachers' Cognitive Structure On The Concept Of"Osmosis" Through The Free Word-Association Test And The Drawing-Writing Technique, original title: Biyoloji Öğretmen Adaylarının Bağımsız Kelime İlişkilendirme Testi ve Çizme-Yazma Tekniğiyle "Osmoz" Kavramı Konusundaki Bilişsel Yapılarının Belirlenmesi. Turkish Studies-International Periodical for the Languages, Literature and History of Turkish or Turkic, 8(12), 809-829.

Linder, C. J. (1993). A Challenge to conceptual change. Science Education, 77(3), 293-300. https://doi.org/10.1002/sce.3730770304

Miles, M.B., \& Huberman, A.M. (1994). Qualitative Data Analysis: An Expanded Sourcebook (2nd ed.). Thousand Oaks, California: SAGE.

Nakiboğlu, C. (2008). Using word associations for assessing non major science students'knowledge structure before and after general chemistry instruction: the case of atomic structure, Chem. Educ. Res. Pract., 9, 309-322. https://doi.org/10.1039/B818466F

Nakipoğlu, C., Benlikaya, R., \& Bahar, M. (2002). Kelime iletişim testi kullanılarak kimya öğretmen adaylarının atom konusu ile ilgili bilşsel yapılarının incelenmesi. V. Fen Bilimleri ve Matematik Ĕgitimi Kongresi, ODTÜ, Ankara.

Nartgün, Z. (2006). Fen ve Teknoloji Öğretiminde Ölçme ve Değerlendirme. (Edit. Mehmet Bahar) Fen ve Teknoloji Öğretimi(pp.355-415) Ankara: Pegema Yayınc1lık.

Özatlı, N. S. (2006). Öğrencilerin Biyoloji Derslerinde Zor Olarak Algıladıkları Konuların Tespiti ve Boşaltım Sistemi Konusundaki Bilişsel Yapılarının Yeni Teknikler Ile Ortaya Konması. Yayınlanmamış Doktora Tezi, Balıkesir Üniversitesi Fen Bilimleri Enstitüsü Biyoloji Eğitimi Anabilim Dalı, Balıkesir

Özcan, H. (2006). İlköğretim ve Yüksek Öğretim Öğrencilerinin Farklı Disiplin Alanları Açısından Enerji Konusu Üzerine Kavramsal Anlamaları. Balıkesir Üniversitesi, Fen Bilimleri Enstitüsü.

Riche, R. D. (2000). Strategies for Assisting Students Overcome Their Misconceptions in High School Physics. Memorial University of Newfoundland Education 6390.

Yalvaç, G. H. (2008). İşbirlikli Öğrenme Yaklaşımının Öğretmen Adaylarının Çevreye İliş̧kin Zihinsel Yapılarına Etkisi. Yayınlanmamış Yüksek Lisans Tezi, Abant İzzet Baysal Üniversitesi Sosyal Bilimler Enstitüsü, İlköğretim Anabilim Dalı, Fen Bilgisi Öğretmenliği Bilim Dalı, Bolu.

Yıldırım, A. (1996). Disiplinlerarası Öğretim Kavramı ve Programlar Açısından Doğurduğu Sonuçlar. Hacettepe Üniversitesi Eğitim Fakültesi Dergisi, 12, 89-94

YÖK/Dünya Bankası. (1997). Fizik Öğretimi. Milli Eğitimi Geliştirme Projesi.

Yüce, Z., \& Önel, A. (2015). Fen Bilgisi Öğretmen Adaylarının Biyoçeşitliliğge İlişkin Kavramsal İlişkilendirme Düzeyleri. Abant İzzet Baysal Üniversitesi Eğitim Fakültesi Dergisi, 15(1), 326-341. https://doi.org/10.17240/aibuefd.2015.15.1-5000128609

Yücel Ö.E., \& Özkan, M. (2014). Fen Bilimleri Öğretmen Adaylarının Çevre Algılarının Kelime İlişkilendirme Aracılığıyla Belirlenmesi, e-Uluslararası Ĕ̆itim Araştırmaları Dergisi, 5(4), 41-56. 